
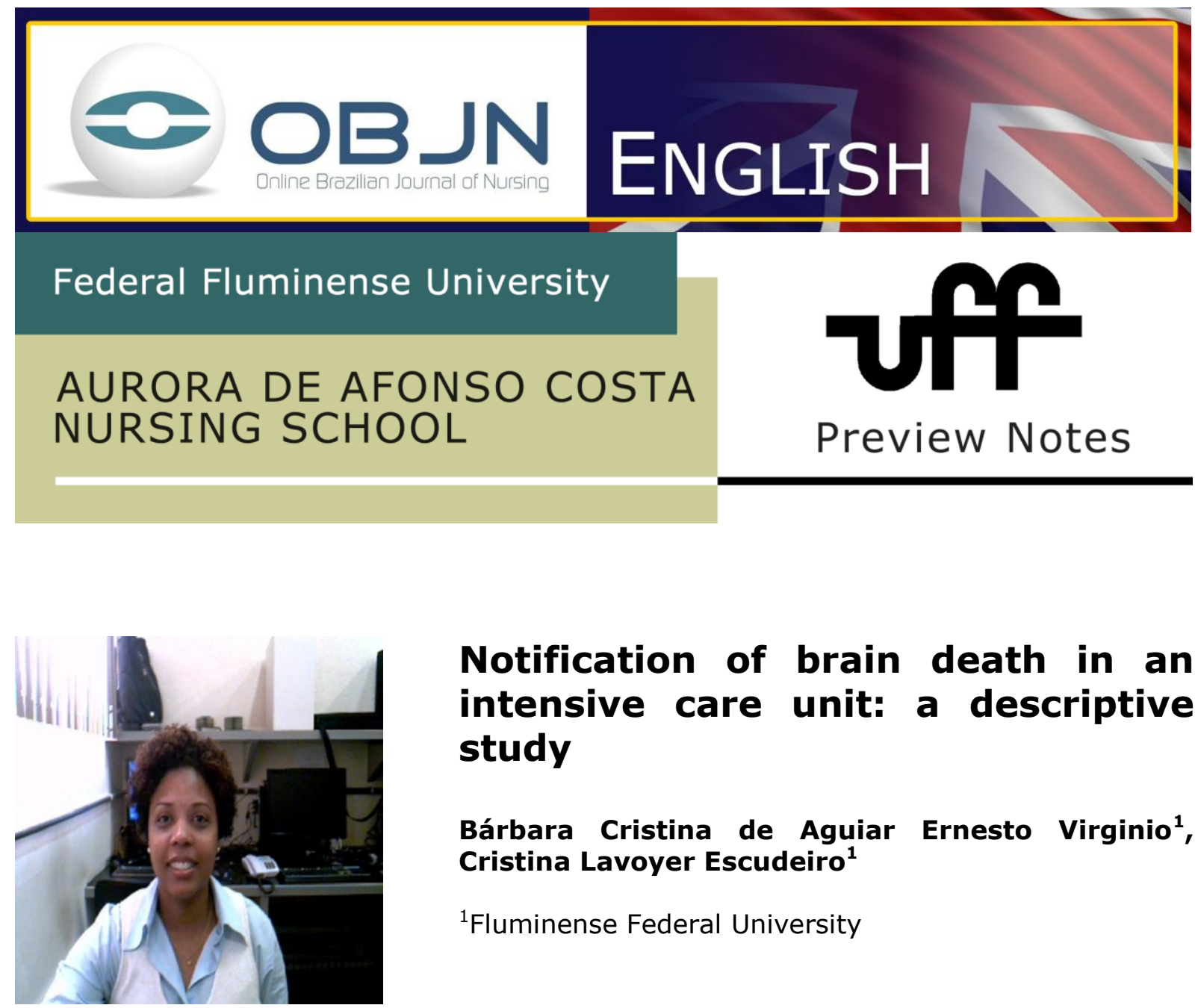

\title{
Notification of brain death in an intensive care unit: a descriptive study
}

\section{Bárbara Cristina de Aguiar Ernesto Virginio", Cristina Lavoyer Escudeiro ${ }^{1}$}

${ }^{1}$ Fluminense Federal University

\begin{abstract}
This study will address the issue of brain death (BD) in an Intensive Care Unit and is linked to the Master's program in Professional Nursing Care of Fluminense Federal University. Objectives: To identify the knowledge of nurses in an intensive care unit regarding the notification process of brain death; to describe the facilities and difficulties encountered by nurses in the process of notification of BD and; to discuss the process of notification of BD and its implications for the donation and capturing of organs. Method: This is a descriptive study, in which we shall use a qualitative approach. The study setting is the intensive care unit of a public hospital, a large scale notifier, located in Niterói. The subjects are nurses employed within the sector.
\end{abstract}

Keywords: Brain Death; Organ Transplantation; Notification 


\section{PROBLEM SITUATION AND ITS SIGNIFICANCE}

Nursing care in the intensive care unit (ICU) requires, from the nurse as part of a multidisciplinary team, specific scientific knowledge with regard to critical patient care. As a result of technological development, the transplantation of organs and tissues has become a therapeutic procedure for patients with disorders for which no conventional therapies are effective, thus raising new possibilities for the treatment for patients with intractable diseases which are of significant relevance in Brazil ${ }^{(1)}$. In this context, the notification of brain death is a crucial action for achieving success in increasing potential donors. This requires, on the part of nurses, pathophysiological knowledge of this process and its peculiarities in order to assist potential donors. After the confirmation of the diagnosis of brain death, the notification of such brain death to the Center of Notification, Organ Procurement and Distribution of Rio de Janeiro (RJ-CNCDO), is the multidisciplinary team's responsibility, since speed in the process of the notification of brain death is of fundamental importance.

The nurse, given his/her scientific knowledge, has the ability to evaluate patients with clinical signs of BD. However, studies on how nurses cope in terms of patient care and dealing with family point out that throughout the whole process of dying in hospitals, a new model of care is recommended which recognizes the partnership between nurses, doctors and family in care situations at the end of life $\mathrm{e}^{(2)}$.

During a seven year period taking care of na ICU of a major hospital, whose environment is characterized by neurological disease processes and/or post-operative neurosurgical disorders, it is observed that the recovery of these patients is marked by prolonged hospitalization, and sometimes progresses to clinical brain death, culminating in death. This hospital is referenced for kidney transplants. However, the institution lacks specific routines for notification situations. Another event that links with the lack of notification is the delay in the assessment of clinical signs and subsequent diagnosis, as well as the absence of an Intra-Hospital Organ and Tissue Donation Commission for Transplantation (IHOTDCT), which facilitates the whole exchange process in an UTI, Center of Notification 
and Capture of Organs of Rio de Janeiro, and the family of the potential donor. With this study we intend to contribute to a better development of practices as part of the notification process, bringing benefits to the institution and society.

\section{GUIDING QUESTIONS}

What is the knowledge of the nursing staff about the process of the notification of BD? What facilities exist, and what are the difficulties encountered in the process of notifying $\mathrm{BD}$ ?

How does the process of the notification of BD happen in an ICU?

\section{AIM}

General aim: Identify the knowledge of nurses of an intensive care unit regarding the notification process associated with brain death (BD).

Specifications aim: To describe the facilities and difficulties encountered by nurses in the process of notifying $B D$; To discuss the process of the notification of $B D$ in a intensive care unit and its implications for the donation and capture of organs.

\section{METHOD}

This is a descriptive study, in which we shall use a qualitative approach. The study setting will be the intensive care unit of a public hospital, a large scale notifier, located in Niterói. The study subjects are the nurses employed in the sector. For data collection purposes we shall use semi-structured interviews. A script of questions will be developed from the objectives of the study and characterization of the subjects. The data will be treated using content analysis, enabling the organization of the results into 
categories. These will allows the grouping of elements or aspects with common characteristics, or which relate to each other ${ }^{(3)}$.

The study was approved under Opinion No 279/11, by the Research Ethics Committee of the hospital that will be the field of this study, ensuring that we will respect the ethical and legal principles related to research with human beings.

\section{REFERENCES}

1- Andrade EF, Boing JS, Grando SR, Licheski AP, Massaroli A, Siqueira KA, et al. O Processo de Captação e Transplante de Órgãos e Tecidos: principais dúvidas dos acadêmicos do sétimo período de um Curso de Graduação em Enfermagem de Santa Catarina [artigo na internet]. [cited 2011 Jan 17]. Available from: www.abennacional.org.br/2SITEn/Arquivos/N.069.pdf

2- Vedootto D. Silva R. Humanization with the family in na intensive care unit: a descriptive study. Online braz j nurs [serial in the Internet]. 2011 Jan; [Cited 2012 May 5]; 9(3). Available from: http://www.objnursing.uff.br/index.php/nursing/article/view/3135

3- Gomes R. Análise e interpretação de dados de pesquisa qualitativa. In: Minayo MC, organizadora. Pesquisa Social: teoria, método e criatividade. 29a ed. Petrópolis: Vozes; 2010.

\section{Project Data}

Dissertation Project of Masters in Professional Care Nursing of Fluminense Federal University, approved on November 24, 2011.

Approval in CEP in $02 \backslash 12 \backslash 2011$, No opinion: 279/11.

Advisor: Prof. Dr. Cristina Lavoyer Squire

Financial Support for the Research: Nursing Regional Council (COREN)

Mailing Address: Bárbara Cristina de Aguiar Ernesto Virginio. Rua Martins Torres, 606, bl 4, apto 202- Santa Rosa- Niterói-RJ. CEP: 24240-705. E-mail: baguiar75@gmail.com

\section{Received: $16 / 02 / 2012$}

Aproved: 03/09/2012 